Article

\title{
Boosting the Higher Heating Value of Eucalyptus globulus via Thermochemical Liquefaction
}

\author{
Frederico Fernandes ${ }^{1}$, Sandro Matos ${ }^{1}$, Daniela Gaspar ${ }^{1}$, Luciana Silva ${ }^{1} \oplus$, Ivo Paulo ${ }^{1}$, Salomé Vieira ${ }^{1}$, \\ Paula C. R. Pinto ${ }^{2}$, João Bordado ${ }^{1}$ and Rui Galhano dos Santos ${ }^{1, *(D)}$ \\ 1 CERENA-Centre for Natural Resources and the Environment, Instituto Superior Técnico, Av. Rovisco Pais, \\ 1049-001 Lisboa, Portugal; fredericoairesfernandes@gmail.com (F.F.); sandro.matos@tecnico.ulisboa.pt (S.M.); \\ danielafbgaspar@tecnico.ulisboa.pt (D.G.); lbsilva@fc.ul.pt (L.S.); ivo.p1691@gmail.com (I.P.); \\ salomevieira@tecnico.ulisboa.pt (S.V.); jcbordado@ist.utl.pt (J.B.) \\ 2 RAIZ-Forest and Paper Research Institute, Quinta de S. Francisco, 3801-501 Eixo, Portugal; \\ paula.pinto@thenavigatorcompany.com \\ * Correspondence: rui.galhano@ist.utl.pt
}

check for updates

Citation: Fernandes, F.; Matos, S.; Gaspar, D.; Silva, L.; Paulo, I.; Vieira, S.; C. R. Pinto, P.; Bordado, J.; Galhano dos Santos, R. Boosting the Higher Heating Value of Eucalyptus globulus via Thermochemical Liquefaction. Sustainability 2021, 13, 3717. https:// doi.org/10.3390/su13073717

Academic Editors: Adam Smoliński and Jorge Rodríguez-Chueca

Received: 19 February 2021

Accepted: 24 March 2021

Published: 26 March 2021

Publisher's Note: MDPI stays neutral with regard to jurisdictional claims in published maps and institutional affiliations.

Copyright: (c) 2021 by the authors. Licensee MDPI, Basel, Switzerland. This article is an open access article distributed under the terms and conditions of the Creative Commons Attribution (CC BY) license (https:// creativecommons.org/licenses/by/ $4.0 /)$.

\begin{abstract}
Biomass can be envisaged as a potential solution to mitigate the problems that the extensive exploitation of fossil sources causes on the environment. Transforming biomass into added-value products with better calorific properties is highly desired. Thermochemical liquefaction can convert biomass into a bio-oil. The work herein presented concerns the study of direct liquefaction of Eucalyptus globulus sawdust. The main goal was to optimise the operating conditions of the process to achieve high bio-oil conversion rates. Studies were carried out to understand the impact of the process factors, such as the residence time, catalyst concentration, temperature, and the biomass-to-solvent ratio. The E. globulus sawdust conversion into bio-oil was achieved with a maximum conversion of $96.2 \%$. A higher conversion was reached when the eucalyptus sawdust's thermochemical liquefaction was conducted over $180 \mathrm{~min}$ in the presence of a $>2.44 \%$ catalyst concentration at $160{ }^{\circ} \mathrm{C}$. A lower biomass-to-solvent ratio favours the process leading to a higher conversion of biomass into bio-oil. The afforded bio-oil presented a better higher heating value than that of E. globulus sawdust.
\end{abstract}

Keywords: sustainable; eucalyptus; liquefaction; biofuels

\section{Introduction}

Most environmental pollution, global warming, domestic energy shortage, economic crisis, and crude oil import dependency are embedded in the distorted exploitation of fossil fuels for electricity generation, transportation, industries, and agriculture [1]. The issues related to the decreasing fossil fuel resources and environmental concerns have been addressed in the research devoted to biomass utilisation [2]. Such alternatives are essential and crucial for a more sustainable society. These alternatives play a vital role in the successful transition toward a renewable energy future, based on feedstocks' multiplicity to make a diverse array of fuels. The development of various conversion technologies must advocate the three foundations of sustainability: environment, society, and economy [3]. The bioenergy produced from biomass has been envisaged as a promising way out of society's dependence on petroleum.

The 21st century will witness the development of a new organics industry based on biomass refining. The implementation of novel technologies, such as integrated biorefineries-producing energy, fuels, and chemicals-must respect the economic viability, laws, and politics aiming at cleaner and safer chemical industry [4].

The lignocellulosic biomass is mainly composed of cellulose (34-54 wt \%). Cellulose forms a skeleton, enclosed by hemicellulose (19-34 wt \%) and lignin (11-30 wt \%). Such biomass also contains minor compounds like ashes (between $0.5 \mathrm{wt} \%$ in wood and $25 \mathrm{wt} \%$ 
in agricultural wastes) [5]. Lignin is highly resistant to chemical and biochemical degradation, acting as a structure that holds the remaining compounds together, providing the necessary stiffness for the cell walls [6].

In the presence of an acid catalyst, biomass can break down the complex lignocellulosic structure into smaller molecules, and is easily manipulated for different applications. Such a process is referred to as thermochemical liquefaction [6]. During the liquefaction process, the protons donated by the acid catalyst aid in the hydrolysis of the glycosidic bonds. These linkages are dominant in cellulose and hemicellulose structures. [7] This process is suitable for any biomass type, such as agriculture [6,8-10], lignocellulosic biomass [11-14], sludges [15], and food waste [16-18].

Domingos et al. [19] studied liquefied eucalyptus branches (Eucalyptus globulus). The process occurred at $180^{\circ} \mathrm{C}$ for $120 \mathrm{~min}$, and a mixture of glycerol and ethylene glycol was used as a solvent. The reaction's catalysis occurred with a concentration of $3 \%(w / w)$ of sulfuric acid. The process's conversion yield was $61 \%$ with a biomass-to-solvent ratio of 1:1, and $72 \%$ using a ratio of $1: 9$. However, the amount of solvent needed was relatively high, and glycerol tends to lead to highly viscous products. Mateus et al. [6] studied the bark of E. globulus's direct liquefication within this context. The impact that temperature variation $\left(120-180^{\circ} \mathrm{C}\right)$ and reaction time $(20-240 \mathrm{~min})$ had on the liquefication of this biomass was assessed. The eucalyptus bark was liquefied in the presence of p-toluenesulphonic acid at a concentration of $3 \%$. A mixture of diethylene glycol and 2-ethyhexanol was used, although the biomass-to-solvent ratio used was also high at 1:9 [6].

The goal of the present work was to optimise the operating conditions of the process to achieve high bio-oil conversion rates. It was also intended to evaluate the potential of the bio-oil to be used as biofuel. The process optimisation study was based on an iteration of some operational parameters separately screened for their effects on biomass conversion. The impact that the variations of reaction time, catalyst concentration, temperature, and the ratio of biomass-to-solvent have on the liquefaction process was studied. Fourier transform infrared-attenuated total reflectance-FTIR-ATR, elemental analysis, and thermogravimetry were used to characterise the bio-oil.

\section{Materials and Methods}

\subsection{Materials and Chemicals}

E. globulus sawdust (44.80\% water content) from RAIZ (Navigator) was used. 2Ethylhexanol and $p$-toluenesulfonic acid, p.a., and technical acetone was acquired from Sigma-Aldrich (St. Louis, MO, USA).

\subsection{Liquefaction Procedure}

The procedure was adapted from the liquefaction of E. globulus bark in diethylene glycol (DEG) and 2-ethylhexanol (2-EH) in the presence of p-toluenesulfonic acid, from work previously developed by Mateus et al. [6], and performed as per the following description. The acid liquefaction process consisted of biomass hydrolysis under atmospheric pressure and temperatures ranging from 120 to $180^{\circ} \mathrm{C}$. 2-EH was used as a unique solvent. The acid catalyst used was $p$-toluene sulfonic acid with a concentration between 0.5 and $3 \%$. The process was carried out from 90 to $300 \mathrm{~min}$, while the biomass-to-solvent ratio was also evaluated from 1:1 to 1:5. A 2 L glass LENZ reactor (with a bottom withdrawal valve) was charged with the biomass, catalyst, and solvent. The reactor was sealed with an O-ring clamped between the reactor neck and a multiple-neck glass lid. The lid was equipped with a Dean-Stark apparatus, a thermocouple (J-type), nitrogen injection, and a stirring shaft. The reaction mixture was mechanically stirred and heated with various temperatures, time periods, catalyst concentrations, and biomass-to-solvent ratios. After that, the reactional mixture was left to cool to $80^{\circ} \mathrm{C}$ and filtered under vacuum conditions. The remaining solid residue was then washed with acetone and dried in an oven at $110{ }^{\circ} \mathrm{C}$ for $24 \mathrm{~h}$. Afterwards, it was weighted for the calculation of the conversion ratio. The 
bio-oils produced were submitted to rotary evaporation to extract the remaining solvent and were further characterised.

\subsection{Measurement of Liquefaction Extent}

The liquefaction conversion was calculated based on the solid residues left from the process after the drying stage, according to Equation (1).

$$
\text { Biomass conversion }(\%)=\left(1-\frac{m_{\text {res }}}{m_{\text {biom }}}\right) \times 100
$$

where $m_{\text {res }}$ stands for the mass of solid residues after drying and $m_{\text {biom }}$ stands for the initial mass of biomass on a dry basis.

\subsection{Elemental Analysis}

The elemental analysis in the bio-oil was performed with a LECO TruSpec CHN to assess the carbon, hydrogen, and nitrogen content, while a LECO CNS2000 determined the sulfur content. Most biomass and its derivatives are composed of up to $97-99 \% \mathrm{C}, \mathrm{H}$, and $\mathrm{O}$. Other elements, like sulfur and nitrogen, are present in lower contents, and thus, are difficult to measure or not so rarely below the detection limit. Consequently, since the bio-oil samples' sulfur and nitrogen content is below the detection limit, it is assumed that they are negligible. Thus, these minor elements are combined into the oxygen content [20], according to Equation (2).

$$
\% \mathrm{O}=100-(\% \mathrm{C}+\% \mathrm{H})
$$

\subsection{High Heat Value (HHV) Determination}

The High Heat Value (HHV) of the bio-oil was calculated using the empirical correlation, according to Dermibas et al. [21], as Equation (3):

$$
\operatorname{HHV}(\mathrm{MJ} / \mathrm{kg})=0.335 \mathrm{C}+1.423 \mathrm{H}-0.154 \mathrm{O}
$$

\subsection{Fourier Transformed Infrared (FTIR-ATR) Analysis}

The FTIR-ATR spectrums were acquired with a Spectrum Two from PerkinElmer (Waltham, MA, USA) equipped with a UATR Two accessory. The spectra were captured in $600-4000 \mathrm{~cm}^{-1}$ with $4 \mathrm{~cm}^{-1}$ resolution and eight scans of data accumulation and treated in Perkin Elmer Spectrum IR software.

\subsection{Thermogravimetric Analysis (TGA)}

The thermogravimetric analysis of the bio-oils and biomass was performed using the Hitachi-STA7200. Before the analyses, the equipment was calibrated following the instructions of the manufacturer. Samples of each bio-oil and biomass were placed in aluminium crucibles and heated from an ambient temperature up to $600{ }^{\circ} \mathrm{C}$, at a heating rate of $10^{\circ} \mathrm{C} / \mathrm{min}^{-1}$, under a $100 \mathrm{~mL} / \mathrm{min}^{-1}$ nitrogen flow.

\section{Results}

This work aimed to optimise the thermochemical liquefaction of E. globulus sawdust. An initial set of conditions was defined based on the literature $[6,22]$. The influence of the catalyst concentration on the biomass conversion was tested, carrying out, for such purpose, the liquefaction for $90 \mathrm{~min}$, at $160^{\circ} \mathrm{C}$ with a biomass-to-solvent ratio of 1:5. The catalyst concentrations of $0.50 \%, 0.99 \%, 1.48 \%, 1.96 \%$, and $2.44 \%(w / w)$ were screened. The experiment conditions and their outcomes are summarized in Table 1. Figure 1a clearly expresses the variations in biomass conversion. The figure shows an increasing profile of the conversion due to an increased catalyst concentration from $52.4 \%$ to $86.1 \%$. This behaviour was expected due to the cellulose hydrolysis mechanism. Due to the higher concentration of protons, the glycosidic bonds' cleavage occurs more easily. That said, and with cellulose accounting for about $50 \%$ of the wood's weight, the phenomenon was 
expected [6]. The gradual increase of the bio-oil conversion, observed with the increased catalyst concentration, reached a plateau for higher concentrations, $2.44 \%$ and $3 \%$. Overall, the highest conversion, $87.2 \%$, was obtained with a $3 \%$ catalyst concentration. However, the slight increase in the conversion, compared with that of the $2.44 \%$ concentration, is not significant. Thus, the $2.44 \%$ concentration is more advisable since it led to good conversion, as did the $3 \%$ concentration, but with less catalyst and, consequently, a lower cost. Moreover, the high acid concentrations are reported as enhancing the recondensation reactions, leading to higher amounts of insoluble residue and decreasing the biomass conversions [23].

Table 1. Liquefaction of eucalyptus sawdust in the presence of different catalyst concentrations.

\begin{tabular}{|c|c|c|c|c|c|}
\hline Run & Biomass/Solvent & $\begin{array}{l}\text { Time } \\
(\mathrm{min})\end{array}$ & $\begin{array}{c}\text { Temperature } \\
\left({ }^{\circ} \mathrm{C}\right)\end{array}$ & $\begin{array}{l}\text { Catalyst } \\
(\% \text { w/w) }\end{array}$ & $\begin{array}{c}\text { Conversion } \\
(\%)\end{array}$ \\
\hline 1 & \multirow{6}{*}{$1: 5$} & \multirow{6}{*}{90} & \multirow{6}{*}{160} & 0.5 & 52.4 \\
\hline 2 & & & & 0.99 & 66 \\
\hline 3 & & & & 1.48 & 74.3 \\
\hline 4 & & & & 1.96 & 82.2 \\
\hline 5 & & & & 2.44 & 86.1 \\
\hline 6 & & & & 3 & 87.2 \\
\hline
\end{tabular}

The influence of the temperature on the eucalyptus sawdust liquefaction process was studied. In this regard, tests were performed with the same operating conditions, varying only the process temperature. Experiments were performed at 120, 140, 160, and $180{ }^{\circ} \mathrm{C}$ for $90 \mathrm{~min}$, with a $2.44 \%(w / w)$ catalyst concentration and a biomass-to-solvent ratio of 1:5 (Table 2). At lower temperatures, 120 and $140{ }^{\circ} \mathrm{C}$, low biomass conversions were observed, below $50 \%$. This behaviour is better understood considering that the eucalyptus constituents' decomposition activation energy (hemicellulose, cellulose, and lignin) are different, lignin having the highest value, followed by cellulose and hemicellulose [6]. It is also necessary to consider the presence of crystalline cellulose, which can affect the process [6]. The decomposition activation energy is higher for crystalline cellulose than for the amorphous counterpart. At low temperatures, the reaction medium's energy is insufficient to break down the cellulose's crystallinity structure and the glycosidic bonds as well. Thus, this may indicate that hemicellulose and amorphous cellulose are the only hydrolysed species at a low temperature.
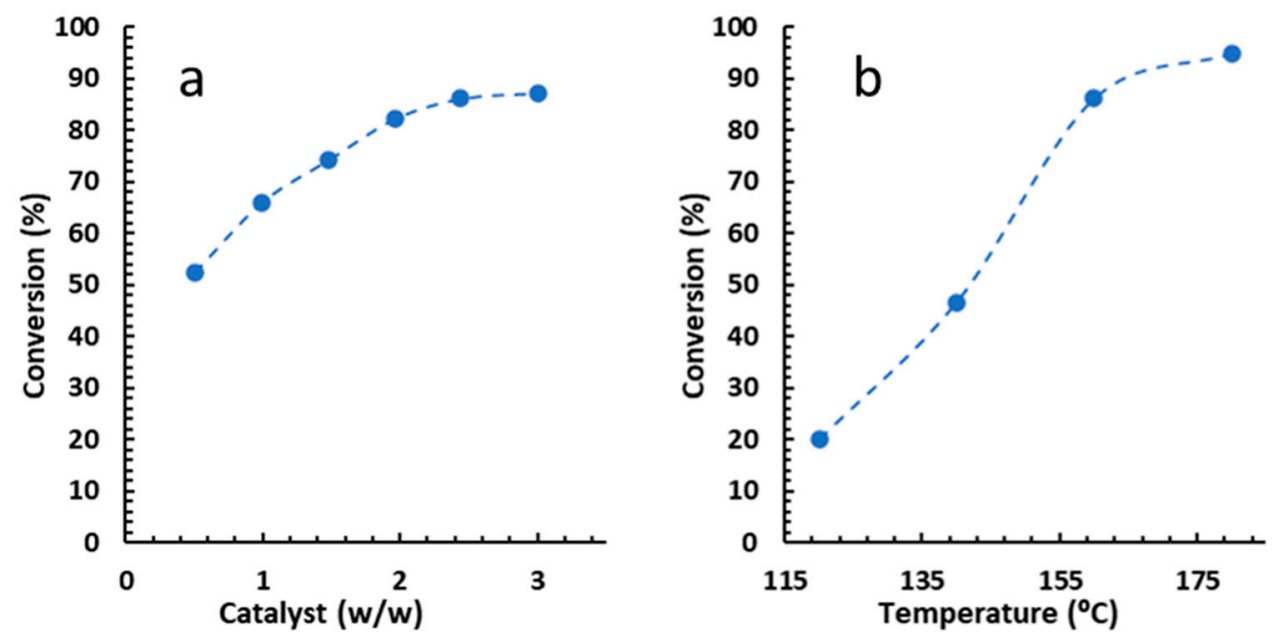

Figure 1. Liquefaction of eucalyptus sawdust under different catalyst concentrations (a) and temperatures $(\mathbf{b})$. 
Table 2. Liquefaction of eucalyptus at different temperatures.

\begin{tabular}{cccccc}
\hline Run & Biomass/Solvent & $\begin{array}{c}\text { Time } \\
(\mathbf{m i n})\end{array}$ & $\begin{array}{c}\text { Temperature } \\
\left({ }^{\circ} \mathbf{C}\right)\end{array}$ & $\begin{array}{c}\text { Catalyst } \\
(\mathbf{\%} w / w)\end{array}$ & $\begin{array}{c}\text { Conversion } \\
(\mathbf{\%})\end{array}$ \\
\hline 7 & & & 120 & & 19.9 \\
8 & \multirow{2}{*}{$1: 5$} & 90 & 140 & 2.44 & 46.6 \\
5 & & & 160 & & 86.1 \\
9 & & 180 & & 94.8 \\
\hline
\end{tabular}

The increase in the reaction temperature, $180^{\circ} \mathrm{C}$, naturally resulted in higher conversion rates than the initial conditions, with a conversion of $91.6 \%$. This effect results from the increase in energy supplied to the reaction medium, facilitating depolymerisation. Figure $1 \mathrm{~b}$ demonstrates that higher conversions are achieved with temperatures above $160{ }^{\circ} \mathrm{C}$.

Some previous studies have addressed the influence of the increase in the biomassto-solvent ratio [24-27] In this regard, the potential of carrying out the liquefaction by decreasing the amount of solvent was investigated. For this purpose, tests were carried out with biomass-to-solvent mass ratios of 1:5, 1:2, and 1:1. To assess this factor's impact on eucalyptus liquefaction, the process was conducted with a $2.44 \%$ catalyst concentration at $180{ }^{\circ} \mathrm{C}$ for $90 \mathrm{~min}$ (Table 3). No visible liquefaction occurred at a high biomass-tosolvent ratio (1:1). After the reaction time, the reactor contained a compact and highly viscous slurry.

Given the aforementioned, it was assumed that the biomass-to-solvent ratio of 1:1 did not allow for the formation of bio-oil due, possibly, to the recondensation reactions of the decomposed lignin units. Pan et al. [28] described such a phenomenon after finding out that lignin's content on liquefaction residues decreased, consistently, when decreasing the biomass-to-solvent ratio. Sarkanen [29] and Kobayashi et al. [30] also reported on the lignin monomer units' tendency to undergo secondary condensation reactions. Pu and Shiraishi [31] further inferred that the lignin content present in the biomass liquefaction residue gradually decreased with a higher amount of solvent and a decreased reaction time. Finally, Pan et al. [28] mention the work developed by Lin [32], which showed that guaiacol, resulting from a reaction of a lignin model compound, was still present at the end of the process due to the existence of an excess of solvent, preventing the nucleophilic reactions. Thus, by increasing the biomass-to-solvent ratio, the solvent can slow down the lignin derivatives' tendency to undergo recondensation reaction. However, the possibility that the solvent reacting with the liquefied lignin to form a new insoluble intermediate retained in the solid residue cannot be ruled out.

Figure 2a clearly demonstrates that the liquefaction process is prone to changes in the biomass-to-solvent ratio. Thus, it is assumed that bio-oil production occurs to a considerable extent only for biomass-to-solvent ratios higher than 1:3, evidence also reported by Boocock and Sherman [27]. The results herein disclosed allude to the difficulty in optimising the process concerning solvent reduction. Thus, the optimal biomass-tosolvent ratio for the liquefaction of eucalyptus sawdust was found to be 1:5, which led to the highest conversion.

Table 3. Liquefaction of eucalyptus at different biomass-to-solvent ratios.

\begin{tabular}{cccccc}
\hline Run & Biomass/Solvent & $\begin{array}{c}\text { Time } \\
(\mathbf{m i n})\end{array}$ & $\begin{array}{c}\text { Temperature } \\
\left({ }^{\circ} \mathbf{C}\right)\end{array}$ & $\begin{array}{c}\text { Catalyst } \\
(\mathbf{\%} w / w)\end{array}$ & $\begin{array}{c}\text { Conversion } \\
\mathbf{( \% )}\end{array}$ \\
\hline 9 & $1: 5$ & & & & 94.8 \\
10 & $1: 2$ & 90 & 180 & 2.44 & 22.4 \\
11 & $1: 1$ & & & & 0 \\
\hline
\end{tabular}



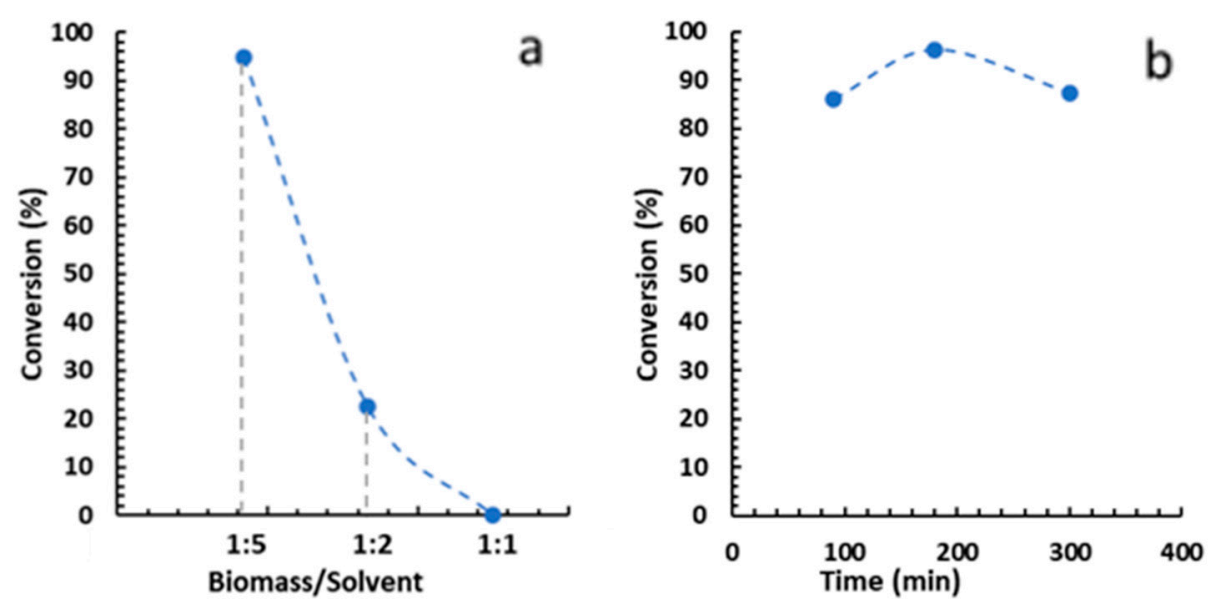

Figure 2. Liquefaction of eucalyptus sawdust under different biomass-to-solvent ratios (a) and times (b).

The study of the influence of the time was conducted at $160{ }^{\circ} \mathrm{C}$. Despite that the boiling temperature of $2-\mathrm{EH}$ is $184.6{ }^{\circ} \mathrm{C}$, in previous experiments at $180{ }^{\circ} \mathrm{C}$, there was considerable evaporation of the solvent. For this reason, to prevent it, the process was conducted at a lower temperature. In doing so, we intended to understand if it would be possible to achieve higher conversions by increasing the liquefaction time, thus avoiding conducting the process at $180{ }^{\circ} \mathrm{C}$, which leads to solvent loss. The study was conducted for $90 \mathrm{~min}, 180 \mathrm{~min}$, and $300 \mathrm{~min}$, at $160{ }^{\circ} \mathrm{C}$, with a $2.44 \%$ catalyst concentration and a biomass-to-solvent ratio of 1:5 (Table 4).

Figure $2 \mathrm{~b}$ demonstrates the influence of time on the extension of the biomass liquefaction. There was a significant increase in the conversion between the first two runs, 90 and $180 \mathrm{~min}$, corresponding to 86.1 and $96.2 \%$ conversions, respectively. After reaching a maximum, the conversion decreased to $87.4 \%$ after $300 \mathrm{~min}$. After $180 \mathrm{~min}$ at $160{ }^{\circ} \mathrm{C}$, it was possible to convert more biomass than at $180{ }^{\circ} \mathrm{C}$ for $90 \mathrm{~min}$, avoiding the solvent's evaporation, as intended. Increasing the reaction time resulted, as expected, in an increase in the reaction's extent and, consequently, in higher conversions. However, after reaching the maximum value, the conversion rate began to decrease, possibly because the decomposition reactions became dominant, leading to the formation of insoluble residues and decreasing the overall liquefaction conversion rate. This effect has already been described for these thermochemical processes. For longer times, tar-type and humin content, which are associated with recondensation reactions or decomposition products, increased $[11,18,33,34]$.

Moreover, the strong network allied to the crystalline part of cellulose, hemicellulose, and lignin makes the biomass resistant to liquefaction. It has been reported that there are initial stages of rapid liquefaction due to the dissolution of easily accessible biomass components, followed by the slower stages that involve the hydrolysis of the less accessible components and those less predisposed to hydrolysis, like crystalline cellulose [35]. Thus, it was expected, as well, that with a longer residence time, the conversion of biomass would increase.

Table 4. Liquefaction of eucalyptus at different residence times.

\begin{tabular}{cccccc}
\hline Run & Biomass/Solvent & $\begin{array}{c}\text { Time } \\
(\mathbf{m i n})\end{array}$ & $\begin{array}{c}\text { Temperature } \\
\left({ }^{\circ} \mathbf{C}\right)\end{array}$ & $\begin{array}{c}\text { Catalyst } \\
(\mathbf{\%} \text { w/w) }\end{array}$ & $\begin{array}{c}\text { Conversion } \\
\mathbf{( \% )}\end{array}$ \\
\hline 5 & & 90 & & & 86.1 \\
12 & $1: 5$ & 180 & 160 & 2.44 & 96.2 \\
13 & & 300 & & & 87.4 \\
\hline
\end{tabular}


The bio-oil from the liquefaction of the eucalyptus sawdust, obtained on Run 12 $(96.2 \%)$, was subjected to elemental analysis. Table 5 shows the content of nitrogen $(\mathrm{N})$, carbon $(\mathrm{C})$, hydrogen $(\mathrm{H})$, sulfur $(\mathrm{S})$, and Oxygen $(\mathrm{O})$, as well as the Higher Heating Value computed from Equation (3) of the bio-oil, as well as that for E. globulus. The results expressed in Table 5 reflect the energetic valorisation that occurred due to the liquefaction process of the eucalyptus sawdust. The elemental analysis of E. globulus, retrieved from the Phyllis2 Database of biomasses [36], shows that this lignocellulosic material has a carbon content of $48.72 \%$, hydrogen content of $5.99 \%$, oxygen content of $44.67 \%$, and negligible quantities of sulfur and nitrogen. The sample subjected to elemental analysis uncovered, given that reference, an increase in the carbon and hydrogen content, of $43 \%$ and $69 \%$, respectively, and a decrease in oxygen content to $61 \%$, which is translated into an increase of the Higher Heating Value. The HHV of the bio-oil reached a value of $34.98 \mathrm{MJ} / \mathrm{kg}$, which represents an increase of about $80 \%$ over the value of E. globulus, $19.44 \mathrm{MJ} / \mathrm{kg}$.

Table 5. Chemical composition and Higher Heating Value (HHV) of E. globulus and bio-oil.

\begin{tabular}{|c|c|c|c|c|c|c|}
\hline \multirow{2}{*}{ Samples } & \multicolumn{5}{|c|}{ Chemical Composition } & \multirow{2}{*}{$\begin{array}{c}\text { HHV } \\
\text { (MJ/Kg }\end{array}$} \\
\hline & $\mathrm{C}$ & $\mathbf{H}$ & $\mathbf{S}$ & $\mathbf{N}$ & $\mathbf{O}$ & \\
\hline E. globulus [36] & 48.72 & 5.99 & 0.01 & 0.39 & 44.67 & 19.44 \\
\hline Bio-oil R12 & 69.53 & 10.14 & $<2$ & $<0.5$ & 17.82 & $34.98 *$ \\
\hline
\end{tabular}

FTIR-ATR experiments on the bio-oil from Run 12 were conducted to identify characteristic signals of the bio-oil sample, corresponding to the biomass's fragments resulting from its liquefaction, Figure 3. The spectra display a band from 3025 to $3630 \mathrm{~cm}^{-1}$, corresponding to $\mathrm{OH}$ groups, and a band from 2079 to $3025 \mathrm{~cm}^{-1}$, typical for the methylene and methyl groups from cellulose, hemicellulose, and lignin [37]. A peak at $1720 \mathrm{~cm}^{-1}$, characteristic of the carbonyl group, was also identified, which can be related to some compounds resulting from cellulose decomposition and oxidation, that is, levulinic acid or furfural [38]. The peaks of $1461 \mathrm{~cm}^{-1}$ and $1178 \mathrm{~cm}^{-1}$, corresponding to $\mathrm{CH} 3-,-\mathrm{CH} 2-$, and $\mathrm{C}-\mathrm{H}$ bend, are related to the presence of carbohydrates and lignin $[6,39]$. The signals at $1516 \mathrm{~cm}^{-1}, 1384 \mathrm{~cm}^{-1}$, and $1031 \mathrm{~cm}^{-1}$ can also confirm lignin derivatives' presence. The first one, $1516 \mathrm{~cm}^{-1}$, corresponds to the $\mathrm{C}=\mathrm{C}$ stretch, while the aromatic $\mathrm{C}-\mathrm{H}$ deformation is usually observed at $1384 \mathrm{~cm}^{-1}$ [6]. The peak of $1031 \mathrm{~cm}^{-1}$ can be assigned to the aromatic C-H in-plane deformation of guaiacyl moieties $[39,40]$. The signal at $1340 \mathrm{~cm}^{-1}$ corresponds to the $\mathrm{C}-\mathrm{H}$ deformation of cellulose and hemicellulose derivatives present on the bio-oil [41]. The C-O-H bend at $1227 \mathrm{~cm}^{-1}$ confirms the existence of the $\mathrm{CH}_{2} \mathrm{OH}$ group from the hexose units [6,42]. At $937 \mathrm{~cm}^{-1}$, a peak usually related to the C-O and C-C stretches, associated with glycoside linkages, is seen. The appearance of this signal confirms the presence of di- or oligosaccharides [6]. The spectra undoubtedly confirm the presence of biomass-based compounds in the bio-oil.

The Thermogravimetric (TG) curves are displayed in Figure 4 and detect weight loss as a function of temperature, the determined thermal stability, the moisture of materials, the volatility of the bio-oil, and the calculation of the carbon residue.

A large stage of degradation dominated the thermal analysis of the samples. For the biomass (Figure $4 \mathrm{a}$ ), the initial weight loss of $3 \%$ at $50{ }^{\circ} \mathrm{C}$ is attributed to the evaporation of water and consequent drying of the material. A zone of thermal stability followed it until $281{ }^{\circ} \mathrm{C}$, where it occurred a loss of $20 \%$, which coincides with the significant degradation of hemicellulose and lignin [43]. The stage at $352{ }^{\circ} \mathrm{C}$ corresponds to the most significant mass loss of $50 \%$, which indicates the degradation of cellulose from the eucalyptus bark. This gave a residual mass of $27 \%$. 


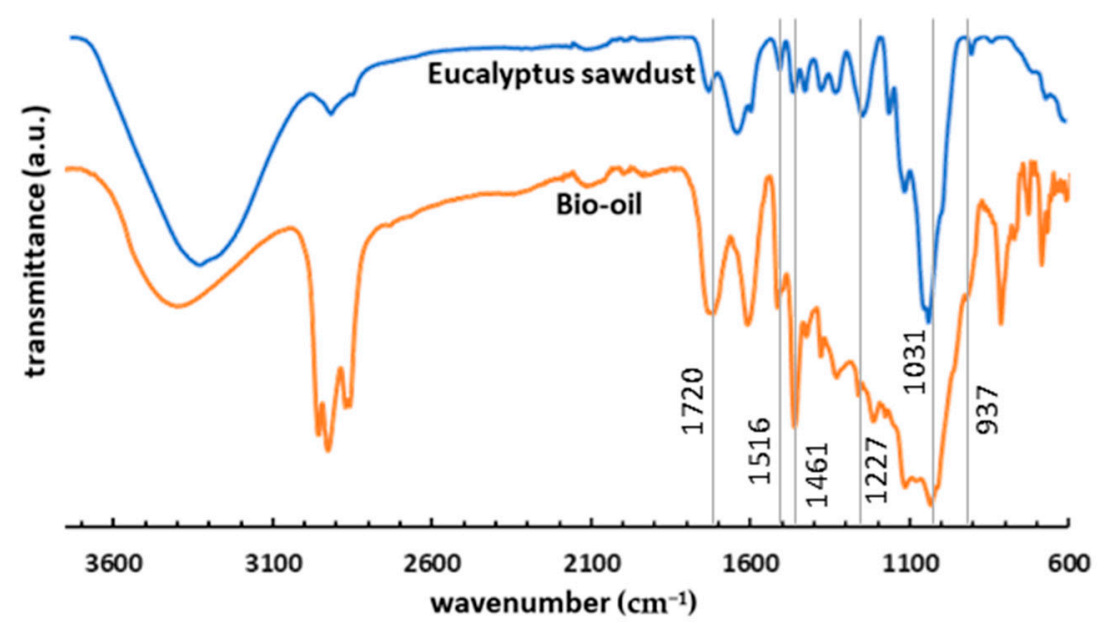

Figure 3. FTIR-ATR spectra of E. globulus and bio-oil (run 12).

The bio-oil (Figure $4 \mathrm{~b}$ ) shows very similar behaviour when compared to the biomass but with mass losses at lower temperatures. The first step of degradation began at $152{ }^{\circ} \mathrm{C}$, where evaporation of the residual solvent 2-ethylhexanol occurred along with the degradation of low molecular compounds from the biomass liquefaction, with a difference of $31 \%$ of the mass. It was followed, at $209^{\circ} \mathrm{C}$, by the main degradation of $35 \%$ of some remaining holocellulose and lignin derivatives. This gave a residual mass of $34 \%$.

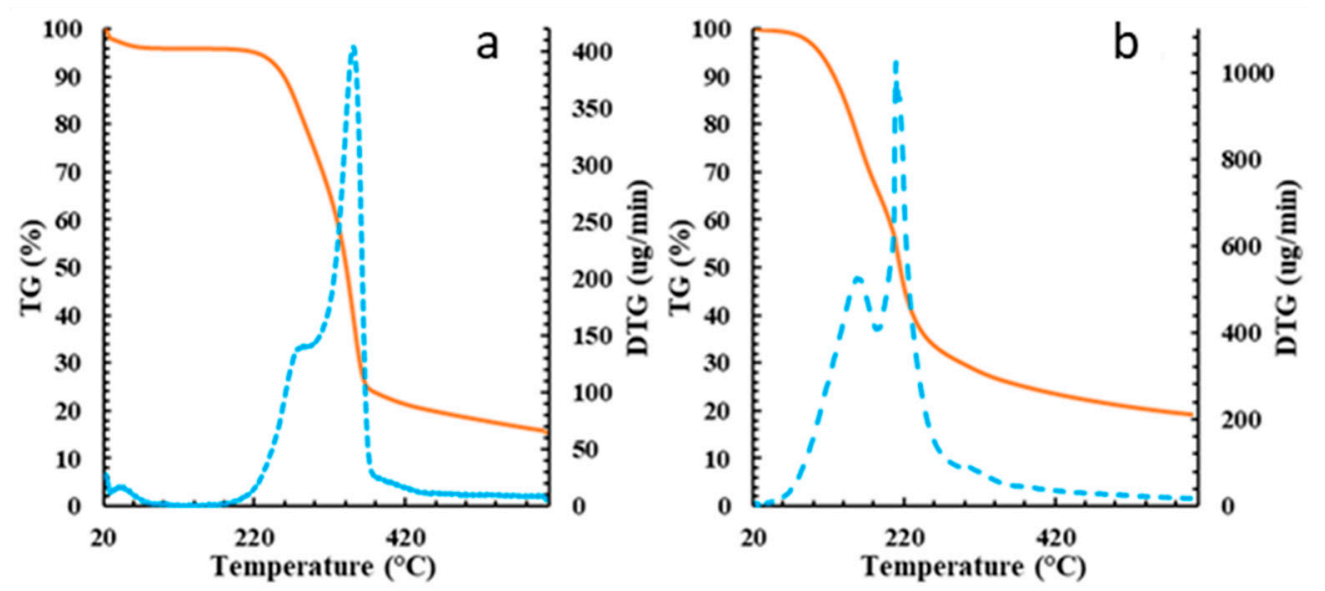

Figure 4. Thermogravimetric curves of E. globulus (a) and bio-oil (Run 12) (b).

\section{Conclusions}

The results disclosed herein allowed us to gather essential information to better understand the liquefaction process of eucalyptus sawdust through acid catalysis. Focusing on process optimisation, and in order to increase the conversion of eucalyptus into bio-oil, it was possible to achieve, in this work, a maximum conversion of $96.2 \%$. Parameters such as the reaction time, catalyst concentration, reaction temperature, and the biomass-to-solvent ratio were evaluated and proved to be decisive for the reaction's extent. In a nutshell, the higher conversion was achieved when the eucalyptus sawdust's thermochemical liquefaction was conducted over $180-300 \mathrm{~min}$, and in the presence of a $>2.44 \%$ catalyst concentration. The preferable temperature was $160^{\circ} \mathrm{C}$, with it being possible to conduct the process at $180^{\circ} \mathrm{C}$ with solvent loss. The biomass-to-solvent ratio of 1:5 led to higher biomass conversion. The elemental analysis of the bio-oil allowed us to calculate its HHV. An HHV value of $34.98 \mathrm{MJ} / \mathrm{kg}$ was computed for the bio-oil. Such a value represents an increase of about $80 \%$ when compared to that of the eucalyptus sawdust. 
Author Contributions: Conceptualisation, resources, methodology-R.G.d.S. and J.B.; liquefaction experiments-F.F., L.S. and S.M.; TGA experiments-D.G.; FTIR experiments-S.V.; writing, reviewing and editing-I.P.; formal analysis- R.G.d.S., J.B., S.V., F.F. and P.C.R.P. All authors have read and agreed to the published version of the manuscript.

Funding: This work was carried out under the Project Inpactus-Innovative Products and Technologies from Eucalyptus, Project N. ${ }^{\circ} 21874$, funded by Portugal 2020 through the European Regional Development Fund (ERDF) in the framework of COMPETE 2020 n²46/AXIS II/2017.

Institutional Review Board Statement: Not applicable.

Data Availability Statement: The data presented in this study are available on request from the corresponding author. The data are not publicly available due to the confidentiality of the project in which it was developed.

Acknowledgments: The authors would like to acknowledge the Forestry and Paper Research Center, RAIZ, and CERENA strategic project (FCT-UIDB/04028/2020).

Conflicts of Interest: The authors declare no conflict of interest. The funders had no role in the study's design, in the collection, analyses, or interpretation of data, or in the writing of the manuscript, but had a position in the decision to publish the results.

\section{References}

1. Rosendahl, L. (Ed.) Direct Thermochemical Liquefaction for Energy Applications; Elsevier: Amsterdam, The Netherlands, 2018; ISBN 9780081010297.

2. Alper, K.; Tekin, K.; Karagöz, S. Hydrothermal Liquefaction of Lignocellulosic Biomass Using Potassium Fluoride-Doped Alumina. Energy Fuels 2019, 33, 3248-3256. [CrossRef]

3. Dahiya, A. Bioenergy: Biomass to Biofuels, 1st ed.; Elsevier Inc.: Amsterdam, The Netherlands, 2015; ISBN 9780124079090.

4. Clark, J.H.; Budarin, V.; Deswarte, F.E.I.; Hardy, J.J.E.; Kerton, F.M.; Hunt, A.J.; Luque, R.; Macquarrie, D.J.; Milkowski, K.; Rodriguez, A.; et al. Green chemistry and the biorefinery: A partnership for a sustainable future. Green Chem. 2006, 8, 853-860. [CrossRef]

5. Doassans-Carrère, N.; Ferrasse, J.-H.; Boutin, O.; Mauviel, G.; Lédé, J. Comparative Study of Biomass Fast Pyrolysis and Direct Liquefaction for Bio-Oils Production: Products Yield and Characterizations. Energy Fuels 2014, 28, 5103-5111. [CrossRef]

6. Mateus, M.M.; Guerreiro, D.; Ferreira, O.; Bordado, J.C.; Galhano dos Santos, R.; dos Santos, R. Heuristic analysis of Eucalyptus globulus bark depolymerization via acid-liquefaction. Cellulose 2017, 24, 659-668. [CrossRef]

7. Xu, J.; Xie, X.; Wang, J.; Jiang, J. Directional liquefaction coupling fractionation of lignocellulosic biomass for platform chemicals. Green Chem. 2016, 18, 3124-3138. [CrossRef]

8. Mateus, M.M.; Gaspar, D.; Matos, S.; Rego, A.; Motta, C.; Castanheira, I.; Bordado, J.M.; Galhano dos Santos, R. Converting a residue from an edible source (Ceratonia siliqua L.) into a bio-oil. J. Environ. Chem. Eng. 2019, 7, 103004. [CrossRef]

9. Wang, C.; Pan, J.; Li, J.; Yang, Z. Comparative studies of products produced from four different biomass samples via deoxyliquefaction. Bioresour. Technol. 2008, 99, 2778-2786. [CrossRef] [PubMed]

10. Wang, H.; Chen, H.-Z. A novel method of utilizing the biomass resource: Rapid liquefaction of wheat straw and preparation of biodegradable polyurethane foam (PUF). J. Chin. Inst. Chem. Eng. 2007, 38, 95-102. [CrossRef]

11. dos Santos, R.G.; Bordado, J.C.; Mateus, M.M. Microwave-assisted Liquefaction of Cork-From an Industrial Waste to Sustainable Chemicals. Ind. Eng. Manag. 2015, 4, 173-177. [CrossRef]

12. Mateus, M.M.; do Vale, M.; Rodrigues, A.; Bordado, J.C.; Galhano dos Santos, R. Is biomass liquefaction an option for the viability of poplar short rotation coppices? A preliminary experimental approach. Energy 2017, 124, 40-45. [CrossRef]

13. Grilc, M.; Likozar, B.; Levec, J. Kinetic model of homogeneous lignocellulosic biomass solvolysis in glycerol and imidazoliumbased ionic liquids with subsequent heterogeneous hydrodeoxygenation over $\mathrm{NiMo} / \mathrm{Al}_{2} \mathrm{O}_{3}$ catalyst. Catal. Today 2015, 256, 302-314. [CrossRef]

14. Braz, A.; Mateus, M.M.; dos Santos, R.G.; Machado, R.; Bordado, J.M.; Correia, M.J.N. Modelling of pine wood sawdust thermochemical liquefaction. Biomass Bioenergy 2019, 120, 200-210. [CrossRef]

15. Galhano dos Santos, R.; Bordado, J.C.; Mateus, M.M. Potential biofuels from liquefied industrial wastes-Preliminary evaluation of heats of combustion and van Krevelen correlations. J. Clean. Prod. 2016, 137, 195-199. [CrossRef]

16. Soares, B.; Gama, N.; Freire, C.S.R.; Barros-Timmons, A.; Brandão, I.; Silva, R.; Neto, C.P.; Ferreira, A. Spent coffee grounds as a renewable source for ecopolyols production. J. Chem. Technol. Biotechnol. 2015, 90, 1480-1488. [CrossRef]

17. Galhano dos Santos, R.; Ventura, P.; Bordado, J.C.; Mateus, M.M. Direct and efficient liquefaction of potato peel into bio-oil. Environ. Chem. Lett. 2017, 15, 453-458. [CrossRef]

18. Mateus, M.M.; Ventura, P.; Rego, A.; Mota, C.; Castanheira, I.; Bordado, J.; dos Santos, R.G. Acid Liquefaction of Potato (Solanum tuberosum) and Sweet Potato (Ipomoea batatas) Cultivars Peels-Pre-Screening of Antioxidant Activity/Total Phenolic and Sugar Contents. BioResources 2017, 12, 1463-1478. [CrossRef] 
19. Domingos, I.J.; Fernandes, A.P.; Ferreira, J.; Cruz-Lopes, L.; Esteves, B.M. Polyurethane foams from liquefied Eucalyptus globulus branches. BioResources 2019, 14, 31-43. [CrossRef]

20. Sheng, C.; Azevedo, J.L.T. Estimating the higher heating value of biomass fuels from basic analysis data. Biomass Bioenergy 2005, 28, 499-507. [CrossRef]

21. Demirbas, A.; Gullu, D.; Çaglar, A.; Akdeniz, F. Estimation of calorific values of fuels from lignocellulosics. Energy Sources 1997, 19, 765-770. [CrossRef]

22. Mateus, M.M.; Bordado, J.C.; Dos Santos, R.G. Potential biofuel from liquefied cork-Higher heating value comparison. Fuel 2016, 174, 114-117. [CrossRef]

23. Wang, Q.; Tuohedi, N. Polyurethane foams and bio-polyols from liquefied cotton stalk agricultural waste. Sustainability 2020, 12, 4214. [CrossRef]

24. Behrendt, F.; Neubauer, Y.; Oevermann, M.; Wilmes, B.; Zobel, N. Direct liquefaction of biomass. Chem. Eng. Technol. 2008, 31, 667-677. [CrossRef]

25. Lee, S.H.; Ohkita, T. Rapid wood liquefaction by supercritical phenol. Wood Sci. Technol. 2003, 37, 29-38. [CrossRef]

26. Pan, H.; Shupe, T.F.; Hse, C.Y. Characterization of novolac type liquefied wood/phenol/formaldehyde (LWPF) resin. Eur. J. Wood Wood Prod. 2009, 67, 427-437. [CrossRef]

27. Boocock, D.G.B.; Sherman, K.M. Further aspects of powdered poplar wood liquefaction by aqueous pyrolysis. Can. J. Chem. Eng. 1985, 63, 627-633. [CrossRef]

28. Pan, H.; Shupe, T.F.; Hse, C.Y. Characterization of liquefied wood residues from different liquefaction conditions. J. Appl. Polym. Sci. 2007, 105, 3739-3746. [CrossRef]

29. Sarkanen, K.V. Wood Chemistry; Wiley: New York, NY, USA, 1963.

30. Kobayashi, M.; Asano, T.; Kajiyama, M.; Tomita, B. Analysis on residue formation during wood liquefaction with polyhydric alcohol. J. Wood Sci. 2004, 50, 407-414. [CrossRef]

31. Pu, S.; Shiraishi, N. Liquefaction of wood without a catalyst, 1: Time course of wood liquefaction with phenols and effects of wood/phenol ratios. J. Jpn. Wood Res. Soc. 1993, 39, 446-452.

32. Lin, L.Z. Characterization of Phenolated Wood and Study on the Liquefaction Mechanism of Lignin. Ph.D Thesis, Kyoto University, Kyoto, Japan, 1996.

33. Hassan, E.M.; Shukry, N. Polyhydric alcohol liquefaction of some lignocellulosic agricultural residues. Ind. Crops Prod. 2008, 27, 33-38. [CrossRef]

34. Pan, H.; Zheng, Z.; Hse, C.Y. Microwave-assisted liquefaction of wood with polyhydric alcohols and its application in preparation of polyurethane (PU) foams. Eur. J. Wood Wood Prod. 2012, 70, 461-470. [CrossRef]

35. Kumar, A.; Sethy, A.; Chauhan, S. Liquefaction Behaviour of Twelve Tropical Hardwood Species in Phenol. Cienc. Tecnol. 2018, 20, 211-220. [CrossRef]

36. Phyllis2-ECN Phyllis Classification. Available online: https://phyllis.nl/Browse/Standard/ECN-Phyllis\#eucalyptus (accessed on 31 January 2021).

37. Mateus, M.M.; Acero, N.F.; Bordado, J.C.; dos Santos, R.G. Sonication as a foremost tool to improve cork liquefaction. Ind. Crops Prod. 2015, 74, 9-13. [CrossRef]

38. Aleme, H.G.; Barbeira, P.J.S. Determination of flash point and cetane index in diesel using distillation curves and multivariate calibration. Fuel 2012, 102, 129-134. [CrossRef]

39. Xiao, B.; Sun, X.F.; Sun, R. Chemical, structural, and thermal characterizations of alkali-soluble lignins and hemicelluloses, and cellulose from maize stems, rye straw, and rice straw. Polym. Degrad. Stab. 2001, 74, 307-319. [CrossRef]

40. Leclerc, D.F. Fourier Transform Infrared Spectroscopy in the Pulp and Paper Industry. Encycl. Anal. Chem. 2006, 11-12. [CrossRef]

41. Mohebby, B. Application of ATR Infrared Spectroscopy in Wood Acetylation. J. Agric. Sci. Technol. 2010, 10, 253-259.

42. Kizil, R.; Irudayaraj, J.; Seetharaman, K. Characterization of irradiated starches by using FT-Raman and FTIR spectroscopy. J. Agric. Food Chem. 2002, 50, 3912-3918. [CrossRef]

43. Maia, A.A.D.; de Morais, L.C. Kinetic parameters of red pepper waste as biomass to solid biofuel. Bioresour. Technol. 2016, 204, 157-163. [CrossRef] 